University of Nebraska - Lincoln

DigitalCommons@University of Nebraska - Lincoln

Publications from USDA-ARS / UNL Faculty

U.S. Department of Agriculture: Agricultural

Research Service, Lincoln, Nebraska

2010

Weed Genomics Advance: A Commentary

Stephen O. Duke

USDA

Jonathan Gressel

Weizmann Institute of Science

Follow this and additional works at: https://digitalcommons.unl.edu/usdaarsfacpub

Part of the Agricultural Science Commons

Duke, Stephen O. and Gressel, Jonathan, "Weed Genomics Advance: A Commentary" (2010). Publications from USDA-ARS / UNL Faculty. 559.

https://digitalcommons.unl.edu/usdaarsfacpub/559

This Article is brought to you for free and open access by the U.S. Department of Agriculture: Agricultural Research Service, Lincoln, Nebraska at DigitalCommons@University of Nebraska - Lincoln. It has been accepted for inclusion in Publications from USDA-ARS / UNL Faculty by an authorized administrator of DigitalCommons@University of Nebraska - Lincoln. 


\section{Weed Genomics Advance: A Commentary}

A recent book edited by Neal Stewart summarized the salient information about the genomics of weeds. ${ }^{1}$ It is a relatively slim volume, in part because so little is known of weed genomics. The rapidly evolving weeds of modern agriculture cry out for understanding their evolution at the genomic level. Still, granting agencies have been reluctant to fund weed genomics in the past, stating that it was enough to support the sequencing of economically important plants (crops), and forgetting that there may be use to sequencing plants that have extremely negative economic impacts on those crops. This attitude has been changing, and the costs have come down. The following two articles make significant additions to the sparse literature on weed genomics. ${ }^{2,3}$ These studies are among the first papers to provide large-scale genomic data sets for major weed species. The authors make good arguments for why the two species chosen are good models to investigate weeds and herbicide resistance.

The first of the two papers is on Amaranthus tuberculatus = A. rudis (waterhemp), a species that has evolved resistance to herbicides of four different mode of action herbicide classes in recent years. ${ }^{2}$ For example, this species evolved resistance to inhibitors of protoporphyrinogen oxidase (PPO) by a complete codon deletion in the PPO gene, ${ }^{4,5}$ rendering PPO resistant to an array of herbicidal PPO inhibitors, while maintaining sufficient catalytic activity for normal porphyrin synthesis. ${ }^{6}$ The authors took advantage of next-generation pyrosequencing technology to produce over 100 million nucleotides of gene sequence. ${ }^{2}$ Such data provide a wealth of information that should benefit future research efforts. This paper not only provides a valuable resource on the genome of Amaranthus tuberculatus, but demonstrates the utility of this information in analysis of genes encoding herbicide target molecules. Eleven herbicide target site genes have now been identified in this species; however, one of the two potential PPO target sites was not found in the BLAST search of the transcriptome data set from this paper, showing the need to perform transcriptome analyses on material at different stages of physiological development.

Conyza canadensis (horseweed), the subject of the second paper, ${ }^{3}$ is a worldwide problem even before it evolved resistance to four herbicide classes in thirteen countries. ${ }^{7}$ In this paper, $95 \mathrm{Mb}$ of transcriptome sequence from a genome estimated to be $335 \mathrm{Mb}$ was read. Comparison with known plant genes identified over 16,000 genes, assigning 13,000 of them putative functions. This paper is a logical extension of a recent paper on the genomics of Conyza canadensis. ${ }^{8}$ The authors demonstrate the utility of the transcriptome-based genomic data base of this paper by using it to identify a putative gene (encoding an $A B C$ transporter) responsible for non-target based glyphosate resistance. These results mesh well with the recent finding that glyphosate-resistant $C$. canadensis sequesters glyphosate in its vacuole, where it can do no harm. ${ }^{9}$

Together, these papers represent the most substantial contribution to weed genomic information yet produced. We hope that these papers are a harbinger of a wealth of genomic information on important weeds, both those in agricultural ecosystems and invasive plant species that threaten natural ecosystems. As firsts, these papers are especially important, both as such and for the information they contain. The authors had to contend with issues such as of the cost of sequencing runs versus the number of samples one should use in comparing wild types with mutants. In first papers of this type, one is interested more in gene discovery per se, whether in one or a hundred plants. When costs come down further, the requirement to better meet typical criteria of sample size will surely go up. The findings in these papers should be considered as qualitative and not definitively quantitative. Still, these studies illustrate the utility of genomic information in probing weed biology questions, pointing the way for those struggling to unravel the bases for weediness.

We thank the reviewers of these papers, especially Burkhard Schulz, who reviewed both papers. Some of their thoughts have been incorporated into this commentary.

Stephen O. Duke, USDA, ARS, Oxford, MS, USA

\section{Jonathan Gressel, Weizmann Institute of Science, Rehovot, Israel}

\section{REFERENCES}

1 Stewart CN (Ed.) Weedy and Invasive Plant Genomics. Wiley-Blackwell, (2009). 253 pp.

2 Riggins CW, Peng $Y$, Stewart CN and Tranel PJ, Characterization of de novo transcriptome for waterhemp (Amaranthus tuberculatus) using GS-FLX 454 pyrosquencing and its application for studies of herbicide target-site genes. Pest Manag. Sci. 66:1042-1052 (2010).

3 Peng Y, Abercrombie LLG, Yuan JS, Riggins CW, Sammons RD, Tranel PJ, et al. Characterization of the horseweed (Conyza canadensis) transcriptome using GS-FLX 454 pyrosequencing and its application for expression analysis of candidate and non-target herbicide resistance genes. Pest Manag. Sci. 66:1053-1062 (2010).

4 Pazoldt WL, Hager AG, McCormick JS and Tranel PJ, A codon deletion confers resistance to herbicides inhibiting protoporphyrinogen oxidase, Proc. Nat. Acad. Sci. U. S. A. 103:12329-12334 (2006).

5 GresselJ and Levy AA Agriculture - the selector of improbable mutations, Proc. Nat. Acad. Sci. U. S. A. 103:12215-12216 (2006).

6 Dayan FE, Daga PR, Duke SO, Lee RM, Tranel PJ and Doerksen RJ, Biochemical and structural consequences of a glycine deletion in the $\alpha-8$ helix of protoporphyrinogen oxidase. Biochim. Biophys. Acta-Proteins and Proteomics, (in press) DOI:10.1016/j.bbapap.2010.04.004. (2010).

7 Heapl, The International Survey of Herbicide Resistant Weeds. Online, Internet, April 22, (2010). Available. http:// www.weedscience.org/In.asp.

8 Yuan JS, Abercrombie LLG, Cao Y, Halfhill MD, Zhou X, Peng Y, Hu J, Rao MR, Heck GR, Larosa TJ, Sammons RD, Wang X, Ranjan P, Johnson DH, Wadl PA, Scheffler BE, Reinhart TA, Trigiano RN and Stewart CN. Functional genomics analysis of horseweed (Conyza canadensis) with special reference to the evolution of non-target-site glyphosate resistance. Weed Sci. 58:109-117 (2010).

9 Ge X, d'Avignon DA, Ackerman JJH and Sammons RD, Rapid vacuolar sequestration: the horseweed glyphosate resistance mechanism. Pest Manag. Sci. 66:345-348 (2010). 